\title{
ASCIDIANS AT CURRAIS ISLANDS, PARANÁ, BRAZIL: TAXONOMY AND DISTRIBUTION
}

\author{
Rosana Moreira da Rocha ${ }^{1}$ \& Suzana Barros de Faria ${ }^{2}$
}

Biota Neotropica v5 (n2) - http://www.biotaneotropica.org.br/v5n2/pt/abstract?article+BN03105022005

Date Received: 09/03/2004

Revised: 09/26/2005

Accepted: 10/10/2005

\begin{abstract}
1 Departamento de Zoologia, Universidade Federal do Paraná, Caixa postal 19020, 81531-980, Brazil. Corresponding author: E-mail: rmrocha@ufpr.br

2 Graduate student, Programa de Pós-graduação em Zoologia, Universidade Federal do Paraná, Brazil. E-mail: suzanabf@ufpr.br
\end{abstract}

\begin{abstract}
The Currais Islands is a group of a few small rocky islands in the state of Paraná, in southern Brazil, which provides an interesting location for the study of ascidians. Subtidal diversity is very high and the islands have recently been proposed as a Conservation Unit. A field study was established on the largest island to understand ascidian distributions on spatial and temporal scales. Transects, sampled three times during 2002 and 2003, were established on northern and southern locations of the island as well as at three depths. Twenty species were recorded; the most common were Didemnum rodriguesi, Didemnum speciosum and Didemnum granulatum. Three species are possibly new and will be described elsewhere. An additional nine are new records for the state of Paraná: Perophora regina, Didemnum speciosum, Trididemnum orbiculatum, Eudistoma carolinense, Aplidium pentatrema, Molgula phytophila, Botryllus tuberatus, Symplegma brakenhielmi and Polyandrocarpa anguinea. While all these species are distributed between 6 and $15 \mathrm{~m}$, there is a tendency to reduction of abundance towards $15 \mathrm{~m}$ in several species. Some species appear to prefer the north side of the island. Several species show temporal changes in abundance, with some being most common in the spring and others in the summer, but we can not affirm yet that there is a seasonal pattern between years.
\end{abstract}

Key words: Ascidiacea, Tunicata, taxonomy, spatial distribution, temporal distribution.

\section{Resumo}

As Ilhas Currais são formadas por um grupo de três pequenas formações rochosas localizadas no Estado do Paraná, sul do Brasil, sendo um local de interesse para o estudo do grupo Ascidiacea. A diversidade da região sublitoral local é bastante alta, e Currais foi recentemente proposto como local a ser transformado em Unidade de Conservação. Foi desenvolvido um estudo de campo na maior das três ilhas, com o intuito de se conhecer a distribuição espacial e temporal de ascídias. Foram realizadas três amostragens entre 2002 e 2003, nos lados norte e sul da ilha, em três diferentes profundidades. Vinte espécies foram registradas, sendo as mais comuns Didemnum rodriguesi, Didemnum speciosum e Didemnum granulatum. Três são possíveis espécies novas e serão descritas futuramente. Nove espécies representam novos registros para o Estado do Paraná: Perophora regina, Didemnum speciosum, Trididemnum orbiculatum, Eudistoma carolinense, Aplidium pentatrema, Molgula phytophila, Botryllus tuberatus, Symplegma brakenhielmi e Polyandrocarpa anguinea. As espécies encontram-se distribuídas principalmente entre a faixa dos seis aos $15 \mathrm{~m}$, tendo sido observada uma redução da abundância em profundidades maiores de 15 m. Algumas espécies parecem preferir o lado norte da ilha. Algumas espécies apresentam variações temporais de abundância, sendo mais comuns ou na primavera ou no verão, mas não é possível ainda afirmar que exista um padrão sazonal entre anos.

Palavras-chave: Ascidiacea, Tunicata, taxonomia, distribuição espacial, distribuição temporal. 


\section{Introduction}

The coastline of the state of Paraná (98 km) includes two important estuarine systems. Rocky substrates are restricted to several small islands near the coast and SCUBA diving in these areas has been limited because of the poor visibility of water. Together, these conditions have resulted in little exploration and knowledge of the fauna in this region, resulting in only two studies of ascidians of Paraná. Didemnum candidum Savigny, 1816 (probably a mixture of white didemnids), Polysyncraton amethysteum (Van Name, 1902) and Styela plicata (Lesueur, 1823) were collected mainly at Mel Island (Moure et al. 1954). Didemnum candidum has not been found again in Brazil and its report was probably an error. An additional 11 species were found by Rocha \& Nasser (1998): Ascidia curvata (Traustedt, 1882), Ascidia sydneiensis Stimpson, 1855, Clavelina oblonga Herdman, 1880, Distaplia bermudensis Van Name, 1902, Didemnum granulatum Tokioka, 1954, Didemnum lutarium Van Name, 1910, Didemnum rodriguesi Rocha \& Monniot, 1993, Diplosoma listerianum (Milne-Edwards, 1841), Cystodytes dellechiajei (Della Valle, 1877), Symplegma rubra Monniot, 1972, and Microcosmus exasperatus Heller, 1978.

Since faunal surveys are far from comprehensive, the distribution patterns of this fauna are still unknown. Due to their sessile and filter-feeding habit, ascidians have limited distribution on soft bottoms because of the lack of substrate for attachment and the clogging effect of the suspended particles. Also, delicate species may be damaged by sand abrasion (Millar 1971, Monniot et al. 1991). Therefore, lower diversity and abundance of ascidians is expected near soft bottoms compared with rocky substrates farther from the bottom. Light may also be an important selection force resulting in specific depth distribution, due to the tendency of ascidian larvae to attach to shadowed substrates (Young \& Chia 1984, Hurlbut 1993). Even species symbiotic with photosynthetic prokaryotes initially settle in crevices or other shadowed places and move into the light later in their life cycles (Olson 1983). Thus, vertical distributions of ascidian species may be strongly influenced by light conditions, while some species show depth preferences that are not clearly associated with light per se (Oren \& Benayahu 1998, Hurlbut 1991). Colonial ascidians are more abundant in shallow water, usually found on vertical and horizontal surfaces, while solitary forms are more abundant in deeper water, inside crevices and underneath rocks (Turon 1990).

This study of the ascidians at Currais Islands in southern Brazil was undertaken to record the species composition of the ascidian community, to describe the species included in this study, and to examine the spatial and temporal distributions of the species forming that community.
Material and Methods

\section{Study site}

The Currais Islands are three small rocky outcrops located 12 km from the coast of the state of Paraná (25S44'; 48 W 22’) in the municipality of Pontal do Paraná. Guapirá Island was the one used in this study; it is the easternmost island and the largest with 54,700 $\mathrm{m}^{2}$. Large granite blocks of varying size comprise the sublittoral zone. Rocky substrates are found to a depth of 15 -- $18 \mathrm{~m}$ where sandy bottoms start. Shallow substrates (down to $6 \mathrm{~m}$ ) are covered by macroalgae, coralline algae and large colonies of zoanthids. Encrusting communities of deeper substrate are dominated by algae, tunicates, sponges, oysters, hydroids and other anthozoan cnidarians (Silva 2001).

Waves may reach $2.4 \mathrm{~m}$ (monthly mean maximum) in September and October. Winds from the east and south prevail (Silva 2001), therefore the island is the most exposed to waves, winds and strong currents on its southern and eastern sides. It is also more exposed during the winter because of cold fronts coming from the south. Diving conditions are variable and water visibility varies from $1 \mathrm{~m}$ to rarely $15 \mathrm{~m}$ (usually $3-5 \mathrm{~m}$ ). Water temperature ranges from $15^{\circ} \mathrm{C}$ during the winter to $24^{\circ} \mathrm{C}$ during the summer.

\section{Sampling}

Ascidians were sampled by SCUBA diving on the southeast and north sides of the largest island during July 2002 (winter), October 2002 (spring), and January 2003 (summer). During those dives, specimens were counted, collected for identification and quantified within small quadrats $\left(5 \times 5 \mathrm{~cm}^{2}\right)$ that were placed uniformly along a transect line at a fixed depth. Only vertical surfaces were sampled to minimize variability due to light, since light is an important recruitment cue for many ascidians (Olson 1983, Young \& Chia 1984, Hurlbut 1993). The presence of ascidian species inside each quadrat was registered.

In July (winter, 07/19/2002), we sampled 20 quadrats at each of two depths (8 $\mathrm{m}$-shallow; $12 \mathrm{~m}$-medium) on the north and south sides of the islands (80 quadrats). Since ascidians were absent in many quadrats, sample size was increased for subsequent sampling. In April (spring, 04/10/ 2002), 60 quadrats were sampled at 6--9 m (shallow) and 20 quadrats at $12 \mathrm{~m}$ (medium) on the north side, 40 quadrats at 8 - 9 m (shallow) and 40 quadrats at 11 - 12 m (medium) on the southern side. In January (summer, 01/31/2003), 40 quadrats at $8 \mathrm{~m}$ (shallow), 40 quadrats at $12 \mathrm{~m}$ (medium) on the north side; 20 quadrats at $8 \mathrm{~m}$ (shallow), 20 quadrats at $12 \mathrm{~m}$ (medium) and 40 quadrats at $15 \mathrm{~m}$ (deep) on the southern side were sampled. To test for species' preferences (nonrandom occurrence) among locations (northern and southern sides of the island) and depth, frequencies were compared by $\mathrm{G}$ tests of independence using contingency tables. 
For identification, specimens collected both within and outside the quadrats were anesthetized with menthol crystals for 90 minutes, then transferred to $10 \%$ seawater formalin. Voucher specimens were deposited in the collection of the Zoology Department of the Federal University of Paraná (DZUFPR) and at the Museum of Zoology of the University of São Paulo (MZUSP).

\section{Results}

Fifteen species were encountered in the samples with an additional five species collected outside the quadrats, to complete the ascidian survey. The most frequent species in the samples were Didemnum rodriguesi Rocha \& Monniot, 1993, Didemnum speciosum (Herdman, 1886) and Didemnum granulatum Tokioka, 1954. One new species (Eudistoma sp.) was found among the species at Currais Islands with possibly two more new species (Didemnum sp., Lissoclinum sp.), while ten species are reported here for the first time from the state of Paraná: Perophora regina Goodbody \& Cole, 1987, Didemnum speciosum, Diplosoma sp., Trididemnum orbiculatum (Van Name, 1902), Eudistoma carolinense Van Name, 1945, Aplidium pentatrema (Monniot, 1972), Molgula phytophila Monniot, 1969-70, Botryllus tuberatus Ritter \& Forsyth, 1917, Symplegma brakenhielmi (Michaelsen, 1904) and Polyandrocarpa anguinea (Sluiter, 1898).

\section{Systematics}

Order ENTEROGONA Perrier, 1898

Suborder PHLEBOBRANCHIA Lahille, 1887

Family PEROPHORIDAE Giard, 1872

Genus Perophora Wiegmann, 1835

Perophora regina Goodbody \& Cole, 1987

(Figure 1A-C)

\section{Examined material}

DZUFPR - PEROPH 013: 1 colony, Currais Islands, south side, 12 m, PR, 19 July 2002.

DZUFPR - PEROPH 014: 1 colony, Currais Islands, north side, PR, 31 January 2003.

DZUFPR - PEROPH 011: 1 colony, Saco d’Água, 10 m, Arvoredo Island, Marine Biological Reserve of Arvoredo, SC, 27 January 2000.

DZUFPR - PERO 016: 1 colony, Alcatrazes Island, north side, SP, 03 May 2002.

The colony comprises ramified stolons from which zooids arise vertically. Zooids are crowded and completely cover the substrate around the stolons. The tunic is transparent and colorless except for two oval white spots between the siphons, one on each side of the neural ganglion, which is covered by a yellow line. The orange stomach can also be seen through the transparent body. Zooids are 2.5 - $3.5 \mathrm{~mm}$ long. The tubular or conical oral siphon has a delicate fringe of six to eight rounded lobes. In anesthetized individuals the margin is nearly smooth, sometimes folding over the siphon and exposing the oral tentacles. The apical, tubular atrial siphon has six to eight rounded lobes. About 22 simple oral tentacles of three sizes are common; one zooid had 35. The circular siphonal muscles are more superficial and conspicuous than are the longitudinal muscles. Oblique muscles on the left side of the thorax are short and do not cover the gut, while on the right side the muscles are remarkably developed. The pharynx has four rows of stigmata, which are posterior to the non-perforated anterior area. The first three pharyngeal rows have about 35 stigmata while the fourth row has about 45 per side. Trifurcating papillae arise from each of the three transversal bars (nine to ten papillae in each half row), some of which form complete longitudinal vessels. Three languets arise from the dorsal lamina. There is a simple ciliated ring and the dorsal tubercle form a small oval aperture. The esophagus is short wider in its proximal end; the stomach is conical or globular without folds; a short duodenal region enters to the tubular posterior stomach. The intestinal loop is straight, not twisted, and the bilobed anus ends between the second and the third row of stigmata. Three stoloniferous vessels arise posteriorly: the middle vessel is short and wide while the other two are thin and long and descend into the peduncle. The gonads are inside the intestinal loop; the testis has 14 or fewer round or pyriform follicles and are found in the central part of the gut loop; the ovary contains four immature oocytes at the base of the sperm duct, just dorsal to the testis. Gonads were not found in the colony collected in July (winter) and an ovary was present only in the colony from Alcatrazes Island (May-fall). Larvae were not seen.

\section{Remarks}

Perophora with four rows of stigmata that occur in the western Atlantic are $P$. viridis Verrill, 1871 and P. regina Goodbody \& Cole, 1987 (Goodbody 1994). The material described here has all the characters described for $P$. regina with the exception of the complete longitudinal vessels. In the Belize material, the vessels are always incomplete (Goodbody \& Cole 1987). The body wall musculature is also important for separating species in this genus (Goodbody 1994). Goodbody \& Cole (1987) did not state whether the left side longitudinal muscles overlap the gut, but the holotype was checked, confirming that they do not in P. regina (Cole, personal communication). 

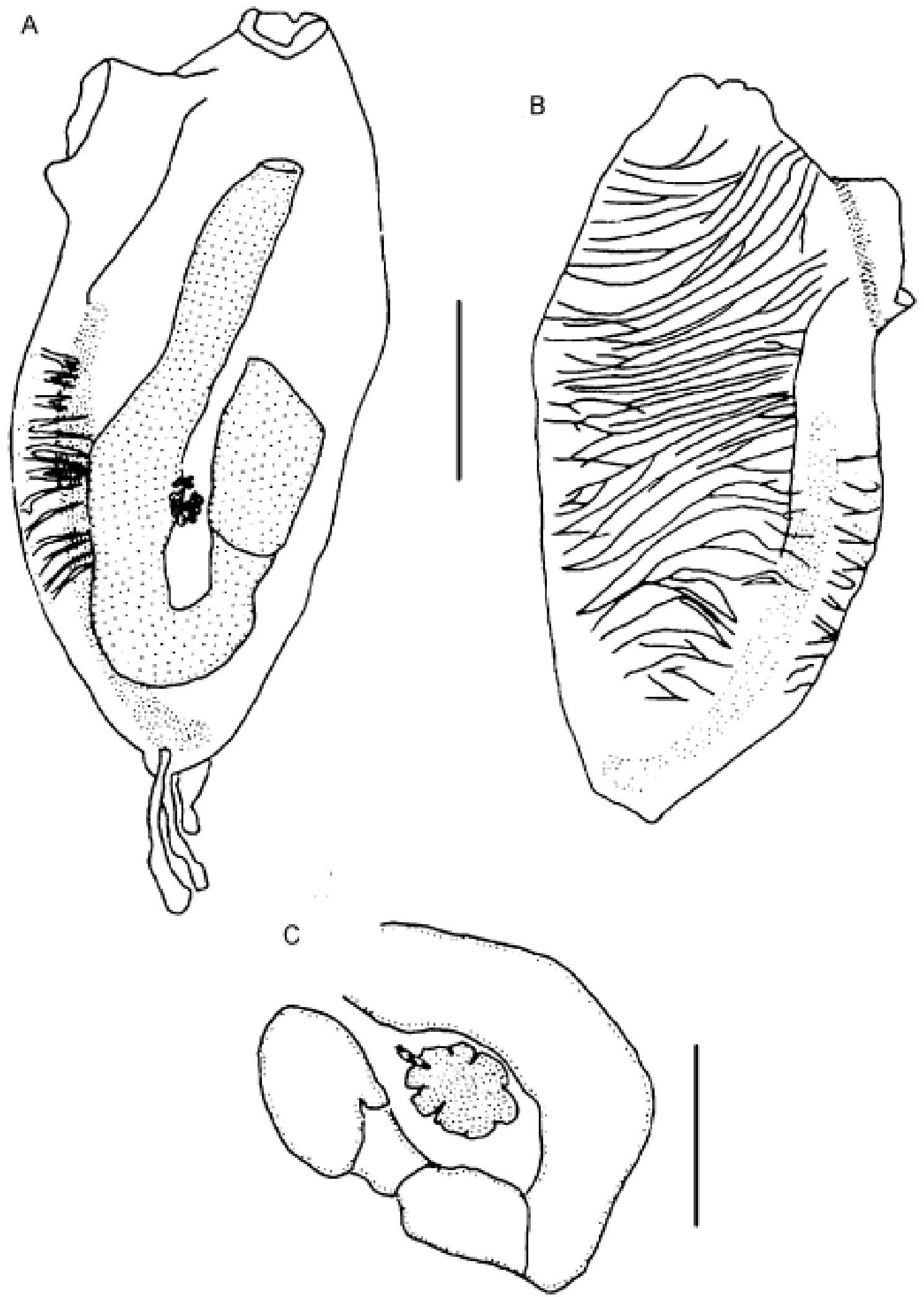

Figure 1. Perophora regina Goodbody \& Cole, 1987. (A) left side of the zooid; (B) right side of the zooid; (C) detail of the abdomen with gonad. Scale bars $=500 \mu \mathrm{m}$. 
Suborder APLOUSOBRANCHIA Lahille, 1887

Family CLAVELINIDAE Forbes \& Hanley, 1848

Genus Clavelina Savigny, 1816

Clavelina oblonga Herdman, 1880

\section{Examined material}

DZUFPR - POLY 049: 1 colony, Currais Islands, PR, south side, 8 m, 19 July 2002.

DZUFPR - POLY 057: 1 colony, Currais Islands, PR, north side, 04 October 2002.

DZUFPR - POLY 061: 1 colony, Currais Islands, PR, 31 January 2003.

DZUFPR - POLY 062: 2 colonies, Currais Islands, PR, north side, 8 and 12 m, 31 January 2003.

DZUFPR - POLY 063: 1 colony, Currais Islands, PR, south side, 15 m, 31 January 2003.

Zooids are linked witch each other only at the base and are about $2 \mathrm{~cm}$ long. They are very transparent, sometimes with a white line on the prepharyngeal grove and on the endostyle. Zooids can be densely packed in the colony or not. The two apertures are circular without lobes. There are 13 oral tentacles of three sizes and 12 - 13 rows of stigmata. The pyriform follicles of the testis lay on the gut loop, around the central ovary. Larvae were present in summer.

\section{Remarks}

There are four species of Clavelina in the tropical Atlantic: C. oblonga Herdman, 1880, C. picta (Verrill, 1900), C. brasiliensis (Millar, 1977) and C. puertosecensis Millar \& Goodbody, 1974. The first three have been reported along the Brazilian coast, but although C. picta was recorded from São Sebastião, SP, (Van Name 1945) it has not since been found there. Millar (1977) collected some specimens in the northern Brazilian coast, which he identified as C. picta. Compared with C. oblonga, $C$. picta has larger colonies with up to 1,000 zooids, the endostyle, dorsal lamina and peripharyngeal bands are purple colored and the larvae have four rows of stigmata (Van Name 1945). Clavelina brasiliensis has long zooids with a cylindrical stalk of firm consistency, the position of oral and atrial openings is subterminal, and the larvae present modified adhesive papillae (Millar 1977), characters not observed in our specimens.

\section{Family POLYCITORIDAE Michaelsen, 1904 \\ Genus Eudistoma Caullery, 1909 \\ Eudistoma carolinense Van Name, 1945}

\section{Examined material}

DZUFPR - POLY 055: 1 colony, Currais Islands, PR, north side, 8 m, 04 October 2002.
DZUFPR - POLY 056: 1 colony, Currais Islands, PR, north side, 04 October 2002.

DZUFPR - POLY 065: 1 colony, Currais Islands, PR, south side, $12 \mathrm{~m}$, 31 January 2003.

DZUFPR - POLY 066: 1 colony, Currais Islands, PR, north side, 31 January 2003.

Colonies are lobed and completely covered with sand. Lobes are 2 to $5 \mathrm{~cm}$ long and compressed laterally. The zooids reach $5.5 \mathrm{~mm}$ in length with three rows of stigmata and 14 - 15 stigmata are found in each half-row. The gonad is formed by the central ovary surrounded by seven to 14 testicular follicles, all of which forms a compact mass. The larval body is $0.3 \mathrm{~mm}$ long with three adhesive papillae and four pairs of ectodermal ampullae.

\section{Remarks}

This species has been reported in northeastern Brazilian coastal waters (Millar 1977) and less than $50 \mathrm{~km}$ south of Currais Islands in the state of Santa Catarina (Rocha \& Moreno 2000), even though it has never been reported from the intervening areas (Lotufo 2002). It is possible that it has been introduced to the southern coast of Brazil through ship transportation.

\section{Family POLYCITORIDAE Michaelsen, 1904 \\ Genus Eudistoma Caullery, 1909 Eudistoma sp.}

\section{Examined material}

DZUFPR - POLY 058: 1 colony, Currais Islands, PR, south side, 04 October 2002.

DZUFPR - POLY 059: 1 colony, Currais Islands, PR, north side, 8 m, 04 October 2002.

The colony is white, with grayish round spots on the surface of each zooid. Colonies are small $(1.5$ x $2.0 \mathrm{~cm}$ and 4 $\mathrm{mm}$ thick) and oval-shaped. The colorless tunic is gelatinous but offers some resistance to tear; the white zooids may be seen through the tunic. Colonies were always found on encrusting coralline algae.

\section{Remarks}

Gonads and larvae were present. This is a new species to be described elsewhere.

Family POLYCLINIDAE Milne-Edwards, 1842

Genus Aplidium Savigny, 1816

Aplidium pentatrema (Monniot, 1972)

(Figure 2A, B) 


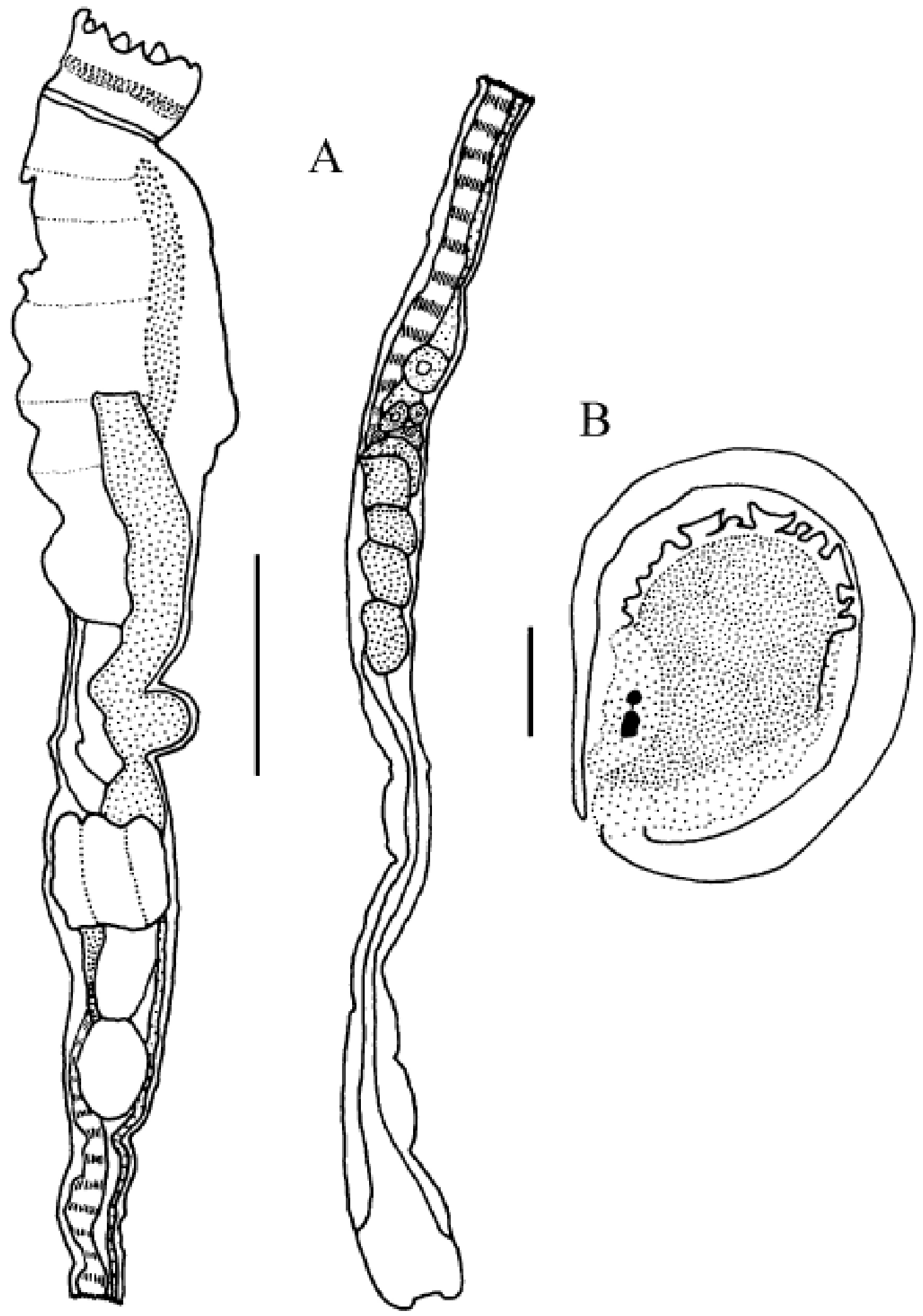

Figure 2. Aplidium pentatrema (Monniot, 1972). (A) Zooid; (B) larva. Scale bars = A, $500 \mu \mathrm{m}$; B, $100 \mu \mathrm{m}$. 
Examined material

DZUFPR - POCL 029: 1 colony, Currais Islands, PR, north side, $8 \mathrm{~m}, 04$ October 2002.

Colonies were brown, encrusting and cushion-like, of $2 \times 3 \mathrm{~cm}$ in area and $8 \mathrm{~mm}$ thick. The tunic is firm, cartilaginous and packed with sand. When alive, zooids form systems that are difficult to observe in preserved specimens. Zooids are $1.2 \mathrm{~cm}$ long with the post-abdomen portion being twice the length of the rest of the body. The apical oral siphon has eight lobes and circular muscles that form a sphincter, while the atrial siphon is lateral, small and circular. A long dorsal languet divides into three points with the middle point longer than the others.

The pharynx has five rows of stigmata with at least 10 stigmata in the first half-row. No more than 10 thin longitudinal muscles are found on each side of the thorax continuing to the end of the post-abdomen. The esophagus is long, the stomach has six folds, the intestine has two constrictions and the bilobed anus is between the third and fourth rows of stigmata. Up to seven embryos were found in the atrial cavity. The oval larvae appear to be immature and are only $0.33 \mathrm{~mm}$ long, with the tail wrapping entirely around the trunk on the left side. Three adhesive papillae form a line with short and thin peduncles. A concentration of epidermal vesicles is found in the anterior region of the larvae. The ocellus and statocyte are visible inside the sensory vesicle.

\section{Remarks}

This species was described from Bermuda under the genus Sidnyum by Monniot (1972). The only difference between the genera Aplidium and Sidnyum is the number of lobes on the oral siphon. Therefore, in agreement with Kott (1992), we suggest that these genera are synonymous and the name Aplidium has precedence. The species described here is very similar to the original description of $A$. pentatrema, the main difference is that the size of the larvae of that species is twice that of the species described herein. This could be explained by the immature aspect of the larvae from Currais. Aplidium appendiculatum (Michaelsen, 1923) from the Azores also have small larvae and eight lobes on the oral siphon, while the thorax is longer with 10 to 12 rows of stigmata (Monniot 1974).

Family HOLOZOIDAE Berrill, 1950

Genus Distaplia Della Valle, 1881

Distaplia bermudensis Van Name, 1902

\section{Examined material}

DZUFPR - POLY 064: 1 colony, Currais Islands, PR, north side, 12 m, 31 January 2003.
The colony is encrusting, approximately $3 \mathrm{~mm}$ thick, with a surface area of $1 \times 1 \mathrm{~cm}$. The preserved tunic is greenish, transparent and soft. Zooids are $1.8 \mathrm{~mm}$ long. The internal characteristics of the zooids correspond to the description in the literature (Van Name 1945).

\section{Remarks}

Gonads were present inside the intestinal loop but larvae were not found.

Family DIDEMNIDAE Verrill, 1871

Genus Diplosoma MacDonald, 1859

Diplosoma listerianum (Milne-Edwards, 1841)

\section{Examined material}

DZUFPR - DID 159: 1 colony, Currais Islands, PR, south side, 12 m, 19 July 2002.

DZUFPR - DID 162: many colonies, Currais Islands, PR, south side 04 October 2002.

DZUFPR - DID 163: many colonies, Currais Islands, PR, north side, 04 October 2002.

The encrusting colony is very thin, transparent and grayish. Dark pigment is found over the abdomen and sometimes the endostyle and oral siphon. Zooids are $0.8 \mathrm{~mm}$ long and the thorax is longer than the abdomen. The margin of the oral siphon is formed by six triangular lobes while the open atrial siphon lacks a dorsal languet. The thorax is transparent, with four rows of stigmata, the first two rows with 14 stigmata, the third with 13 and the last with 12 in each side. A very delicate muscular process is present. The esophagus is short, the stomach is rounded and smooth walled and the anus is not lobed. The testis has two follicles connected to a straight sperm duct. The ovary has four oocytes alongside the testis. A large embryo may be visible inside the abdomen but fully developed larvae are inside the tunic. The larvae are oval and $0.55 \mathrm{~mm}$ in length. The tail extends along the ventral side of the body to the anterior end. There are three adhesive papillae in a line, close together, with long peduncles, and two ectodermal ampullae in each side. The ocellus and statocyte are visible inside the sensory vesicle. Larvae are gemmiparous, with the oozoid and one blastozooid, being present only in colonies collected in October (spring).

\section{Remarks}

Diplosoma macdonaldi Herdman, 1886 was originally described from the state of Bahia in Brazil and is a common species in shallow waters of the West Atlantic (Van Name 1945). Despite the fact that Rowe (1966) considered $D$. macdonaldi and $D$. listerianum synonyms, Lafargue (1968) stated that both were good species the only difference between them being the presence of the muscular process in 
the latter. Kott (2001) recently suggested that the Atlantic specimens should be considered a different species from $D$. listerianum, but her only argument is the geographical distance between Pacific and Atlantic localities. We did not find any consistent morphological characteristics to justify this position and we therefore maintain the south Brazilian specimens as D. listerianum. This is a cosmopolitan species, usually included in lists of nonindigenous species (Lambert 2001), previously found in southern localities along the Brazilian coast (Rocha \& Nasser 1998).

\section{Family DIDEMNIDAE Verrill, 1871 \\ Genus Diplosoma MacDonald, 1859 \\ Diplosoma sp.}

(Figure 3A, B)

\section{Examined material}

MZUSP-15.779: many colonies, Currais Islands, PR, south side, 04 October 2002, and permanent slide.

DZUFPR - DID 177: many colonies, Currais Islands, PR, north side, 04 October 2002.

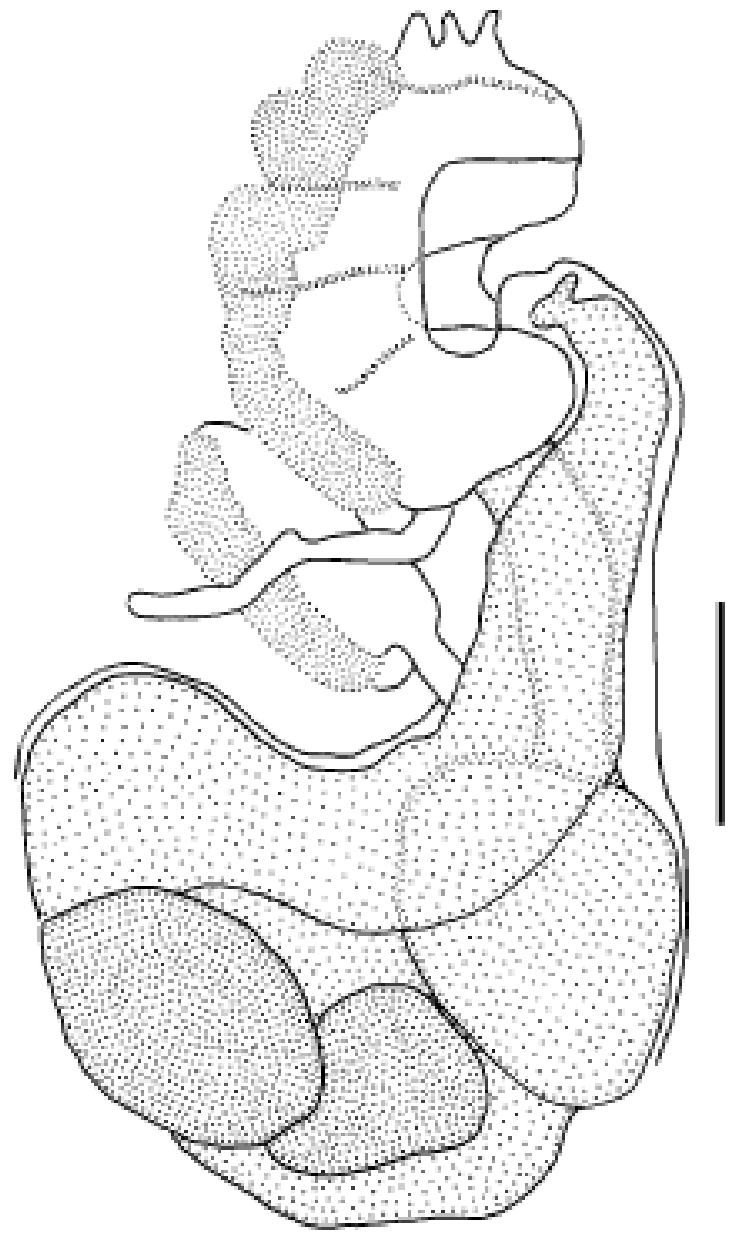

The colony and tunic are very similar to $D$. listerianum, but the black pigment over the abdomen, endostyle and sometimes the oral siphon is more evident. Zooids are $0.7 \mathrm{~mm}$ in length. The margin of the oral siphon comprises six finger-like lobes and the atrial siphon is open, exposing part of the pharynx. There is no dorsal languet. The body wall is opaque, the thorax whitish and the abdomen dark. It was not possible to count the number of stigmata in each of the four rows. The muscular process is present, but short and inconspicuous in many zooids, especially those with developing buds. The testis has two follicles and a straight sperm duct. There is only one embryo developing in the abdomen. The larval trunk is spherical, $0.6 \mathrm{~mm}$ long, over half of which the tail is wrapped on the left side. There are three antero-median adhesive papillae with long and thin peduncles. Ectodermal ampullae, with four to five on the right and five to six on the left side of the trunk, have the following arrangement: six-left/four-right, five-left/four-right and six-left/five-right. In addition to the oozooid, one blastozooid is found. One ocellus and statocyte are found in the sensorial vesicle.

Figure 3. Diplosoma sp. (A) Zooid; (B) larva. Scale bars = A, $200 \mu \mathrm{m} ; \mathrm{B}, 500 \mu \mathrm{m}$.

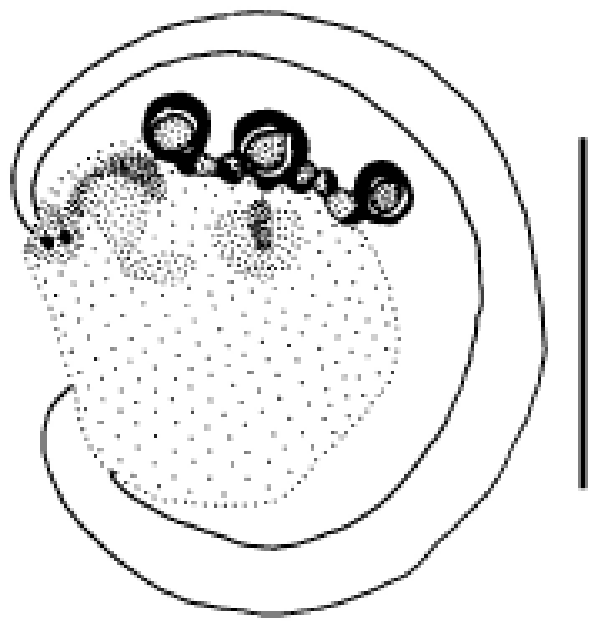


Remarks

Diplosoma listerianum (Herdman, 1886) is the only species known in Brazil, and normally has two pairs of larval ectodermal ampullae. Six other species are known from the Atlantic Ocean and differ from this species as follows: Diplosoma glandulosum Monniot, 1983 from Guadalupe and the Bermudas has a larger zooid (1.75 mm), glandular tissue on the side of the testis, and two pairs of larval ectodermal ampullae; Diplosoma tritestis Monniot, 1984, also from Guadalupe, has a smaller larva $(0.3 \mathrm{~mm})$, testis with three follicles, and only two pairs of ectodermal ampullae; Diplosoma lafargueae Vazquez, 1993 from the Atlantic coast of the Iberian Peninsula, has orange colonies with large zooids $(1.7 \mathrm{~mm})$ without a muscular process; Diplosoma singulare Lafargue, 1968 also from Glenan Archipelago, has an orange colony with larger zooids ( $2 \mathrm{~mm}$ ), without a muscular process, and in spite of the large number of ampullae, has fewer ampullae on each side of the larva compared with our specimen (Lafargue 1968, Lafargue \& Wahl 1987); and finally Diplosoma spongiforme (Giard, 1872) from Glenan Archipelago. This last one is the most similar to the present species but Lafargue \& Wahl (1987) report the following diagnostic characteristics: a long subendostylar thoracic appendix (longer than the abdomen - Lafargue 1968) which was not seen in our material; three to eight adhesive papillae (all the larvae we found had three), and two to seven pairs of ectodermal ampullae in the larvae (we found only four to six). Furthermore, our larvae are smaller than the one described by Lafargue (1968) with a length of $0.8 \mathrm{~mm}$, but they could have been juvenile. Since Diplosoma is known to contain invasive species (Lambert 2001), it is possible that the colonies found at Currais Islands are a population of $D$. spongiforme, but only further genetic investigations would solve the problem.

Among the species not from the Atlantic, the only Diplosoma with a similar larva is Diplosoma ata Monniot \& Monniot, 1987 from French Polynesia and New Caledonia. This larva is 0.55 to $0.8 \mathrm{~mm}$ long and presents two to six pairs of ectodermal ampullae. The zooids also have a small muscular process, but the testis has only one follicle and the oral siphon has long leaf-like lobes (Monniot \& Monniot 1987, Monniot 1994).

Family DIDEMNIDAE Verrill, 1871

Genus Lissoclinum Verrill, 1871

Lissoclinum sp.

(Figure 4A)

Examined material

DZUFPR - LIS 002: 1 colony, Currais Islands, PR, north side, 6 m, 31 January 2003.
The white encrusting colony becomes salmon-colored upon fixation. The tunic is soft, yet resistant and has a smooth surface. In live animals, the cloacae are large and slightly raised with a smooth margin. In the medium layer the tunic is restricted to the contour of the body of the zooids due to the wide cloacal cavities, giving great flexibility to the colony. Spherical spicules, 10 - -20 ìm, with many cylindrical rays and truncated tips, are densely packed in the surface and base of the colony. The zooids were studied from decalcified cross sections of the tunic. Zooids are orange, $0.9 \mathrm{~mm}$ in length with the thorax larger than the abdomen. The thorax is transparent with abundant yellow pigment in each margin of the branchial stigmata. The atrial opening is wide, exposing part of the pharynx, without a dorsal languet. The muscular process is absent. There are four rows of stigmata and in one bud six, six, five, four stigmata were found in each half row. It was not possible to count the stigmata in mature thoraces. The abdomen is opaque and yellowish. The esophageal-rectal peduncle is horizontal and the abdomen makes a right angle with the thorax. Gonads are located in the intestinal loop with the testicle anterior to the ovary. The testicle has two follicles and a straight sperm duct. Larvae, $0.35 \mathrm{~mm}$ in length, were poorly developed in the material.

Remarks

Only two species in the genus Lissoclinum are reported from Brazil: L. fragile (Van Name, 1902) and $L$. perforatum (Giard, 1872) (Lotufo 2002). Lissoclinum fragile is characterized by the whitish color of the colony, even in preserved specimens, and no zooid pigmentation (Rodrigues et al. 1998). Also, the zooid is $1.5 \mathrm{~mm}$ long and the colony has low spicule density (Monniot 1983). On the other hand, the spicules of the present species are very similar to the spicules of $L$. fragile. Lissoclinum perforatum has orange zooids of $2.0 \mathrm{~mm}$ in length and a unique type of spicule, which is larger (500 ìm), in low density, and restricted to the superficial layer of the tunic (Monniot 1983). In the Caribbean there are also Lissoclinum abdominale Monniot, 1983 and Lissoclinum verrilli (Van Name, 1902), each with a single testicular follicle. The species described here is apparently new, but because in didemnids the larva is usually crucial to differentiate species, we prefer not to name the species at present since larvae were not well developed.

Family DIDEMNIDAE Verrill, 1871

Genus Polysyncraton Nott, 1892

Polysyncraton amethysteum (Van Name, 1902)

(Figure 4B)

Examined material

DZUFPR - DID 158: 1 colony, Currais Islands, PR, south side, 12 m, 19 July 2002.

http://www.biotaneotropica.org.br 

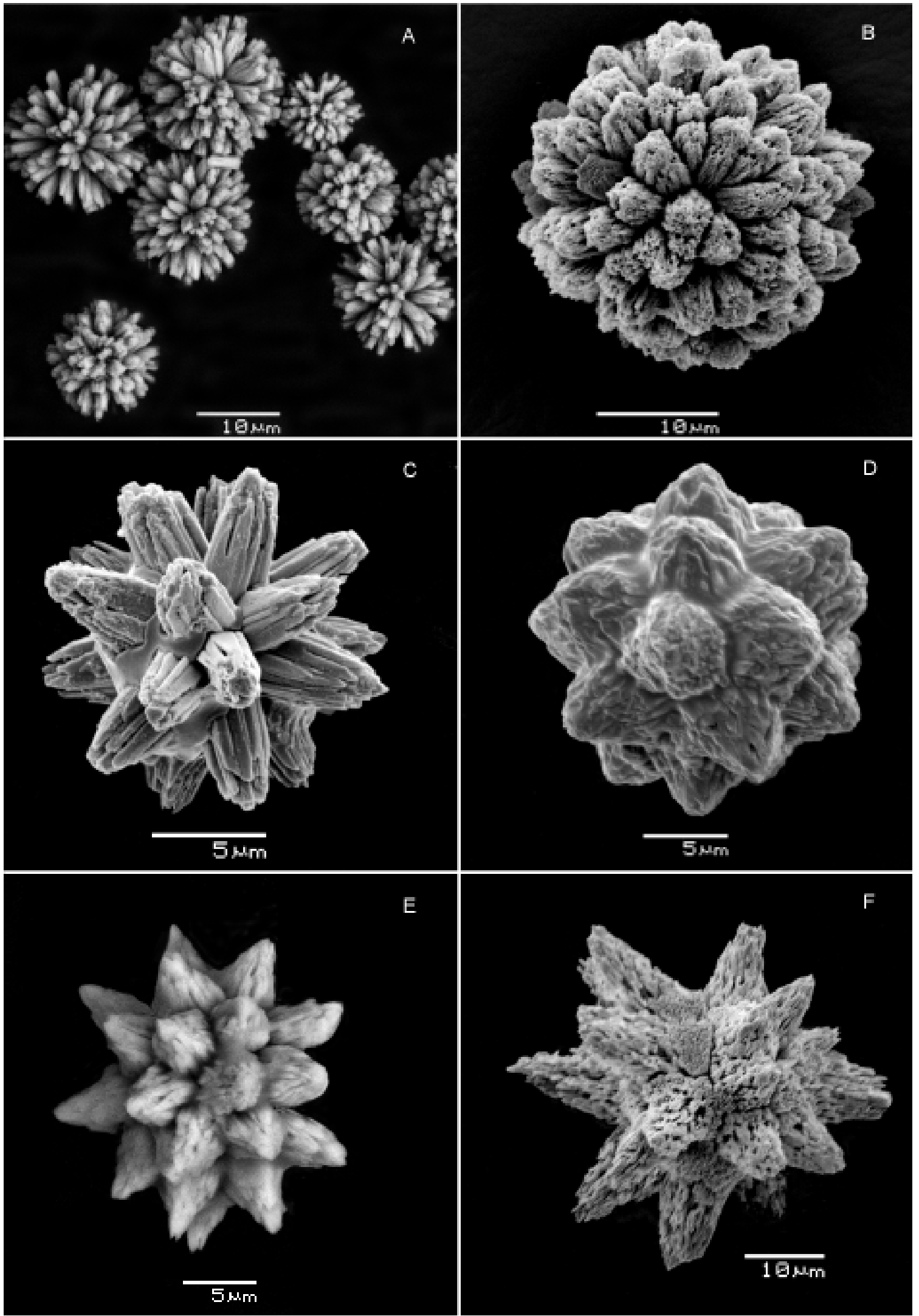

Figure 4. Spicules (A) Lissoclinum sp.; (B) Polysyncraton amethysteum; (C) Didemnum rodriguesi; (D) Didemnum speciosum; (E) Didemnum sp.; (F) Trididemnum orbiculatum.. 
The living colony is encrusting and bright purple, becoming orange after fixation. Several large, circular cloacae are distributed on the colony surface. The colony is transparent due to the low surface spicule density and the absence of spicules in the rest of the tunic. Spicules are only found around the openings of the oral siphons. Zooids are 1-1.3 mm in length. A long dorsal languet narrows towards the base but expands into four finger-like projections distally. The round thoracic organ is located between the endostyle and the border of the mantle and between the first and second rows of stigmata. Gonads were immature and larvae were absent.

\section{Remarks}

This species is a very common in intertidal and shallow subtidal regions along the coast of southeastern and southern Brazil and was recently found in northeastern Brazil (Lotufo 2002).

Family DIDEMNIDAE Verrill, 1871

Genus Didemnum Savigny, 1816

Didemnum rodriguesi Rocha \& Monniot, 1993

(Figure 4C)

\section{Examined material}

DZUFPR - DID 154: 1 colony, Currais Islands, PR, north side, 12 m, 19 July 2002.

DZUFPR - DID 155: 1 colony, Currais Islands, PR, south side, 12 m, 19 July 2002.

DZUFPR - DID 161: 4 colonies, Currais Islands, PR, south side 11-12 m, 04 October 2002.

DZUFPR - DID 172: 3 colonies, Currais Islands, PR, south side $11 \mathrm{~m}, 04$ October 2002.

Small encrusting colonies may form large aggregates that cover relatively large areas of the substrate. The colony is red or bright orange, with a cream-colored ring bordering the oral siphon, becoming yellowish after fixation. The tunic is firm, brittle and packed with spicules. Zooids resemble the original description (Rocha \& Monniot 1993) with the exception that the total length surpasses the $1.2 \mathrm{~mm}$ previously described, measuring up to $1.5 \mathrm{~mm}$ in the examined material. No larvae were present.

\section{Remarks}

This species has been found from Ceará to Santa Catarina (Lotufo 2002).

Family DIDEMNIDAE Verrill, 1871

Genus Didemnum Savigny, 1816

Didemnum cf. granulatum Tokioka, 1954
Examined material

DZUFPR - DID 151: 1 colony, Currais Islands, PR, south side, 12 m, 19 July 2002.

DZUFPR - DID 152: 2 colonies, Currais Islands, PR, north side, 12 m, 19 July 2002.

DZUFPR - DID 153: 1 colony, Currais Islands, PR, south side, 12 m, 19 July 2002.

DZUFPR - DID 166: 3 colonies, Currais Islands, PR, south side, 9-12 m, 10 October 2002.

DZUFPR - DID 167: 1 colony, Currais Islands, PR, south side, $12 \mathrm{~m}, 04$ October 2002.

DZUFPR - DID 168: 1 colony, Currais Islands, PR, north side, 9 m, 04 October 2002.

Colonies are large, encrusting, cream-colored, becoming white after fixation. The surface of the tunic is rough and granulated due to the presence of papillae with a high spicule density. Spicules are similar to the ones figured by Rocha \& Monniot (1995) and Kott (2001). Cloacae are conical with toothed borders. The zooid mantle is transparent and whitish. Thoraces were too contracted to permit counting the number of stigmata. The thoracic organ is circular, placed between the third and fourth rows of stigmata on the border of the body wall. The muscular process is attached to the esophageal-rectal peduncle. Neither gonads nor larvae were found in the material.

\section{Remarks}

Mature gonads and larvae were not found in this material, so we cannot identify this species with certainty. The cream color of the colony differs from that first described (orange, salmon or brown) for the Atlantic Ocean (Rocha \& Monniot 1995). Also, cloacae do not have smooth margins. The color was always described as orange or brick in previous descriptions of this species in Brazil (Rocha \& Nasser 1998, Lotufo 2002) while Tokioka (1954) described the species as small white colonies. Nishikawa (1990) also characterizes D. granulatum with white colonies and zooids with clear orange mantle. Omuro \& Rocha (2000) observed the presence of white colonies of Didemnum granulatum in the Marine Biological Reserve of Arvoredo SC, which indicates that colonies of clear coloration occur in the south of Brazil.

Family DIDEMNIDAE Verrill, 1871

Genus Didemnum Savigny, 1816

Didemnum speciosum (Herdman,1886)

(Figure 4D)

\section{Examined material}

DZUFPR - DID 173: 3 colonies, Currais Islands, PR, south side, 11-12 m, 4 October 2002. 
DZUFPR - DID 174: 2 colonies, Currais Islands, PR, south side, 04 October 2002.

DZUFPR - DID 175: 2 colonies, Currais Islands, PR, south side, 8-2 m, 19 July 2002.

DZUFPR - DID 180: 2 colonies, Currais Islands, PR, south side, 15 m, 31 January 2003.

DZUFPR - DID 181: 1 colony, Currais Islands, PR, north side, 31 January 2003.

DZUFPR - DID 182: 1 colony, Currais Islands, PR, south side, 12 m, 31 January 2003.

The colony is encrusting and white. Star-shaped oral openings occur in small elevations on the colony surface. The tunic is firm and brittle with spicules densely packed. Spicules have several conical rays with rounded tips and are distributed evenly throughout the tunic. Zooids are small, approximately $0.6 \mathrm{~mm}$. The muscular process is short arising from the esophageal-rectal peduncle. The thoracic organ is salient, but visible in only some individuals. Larvae were present only in the material collected in 31 January 2003 (summer). Larval trunk is triangular and only $0.3 \mathrm{~mm}$ long even in mature larvae. The tail makes a complete turn around the trunk, on the left side of the larva. The three adhesive papillae have short and wide stalks, are distant from each other and form a line. Four digitiform ampullae are found on each side of the trunk. The ocellus and statocyte are present.

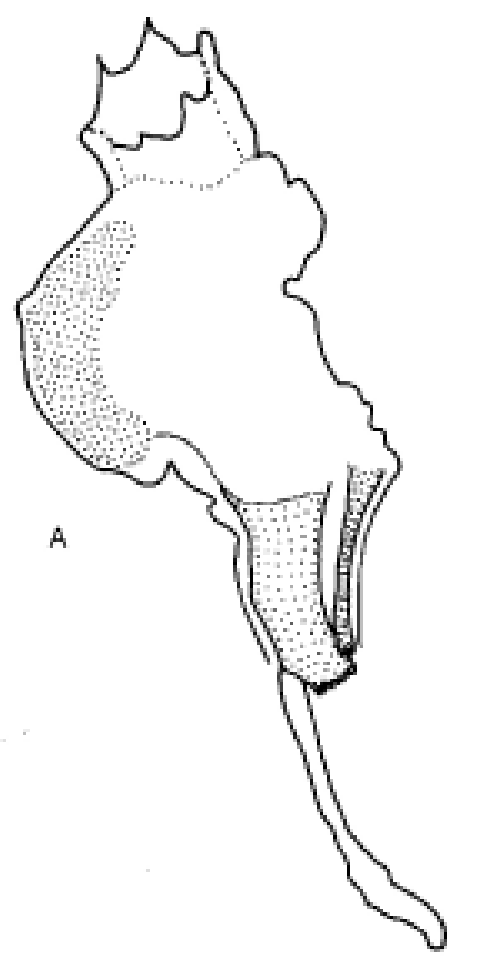

Remarks

Beyond the original locality in Bahia (NE) (Herdman 1886), this species has already been found in São Paulo (Rocha \& Monniot 1995) and north and northeastern Brazil (Millar 1977).

Family DIDEMNIDAE Verrill, 1871

Genus Didemnum Savigny, 1816

Didemnum sp.

(Figures 4E; 5A, B)

\section{Examined material}

DZUFPR - DID 156: 2 colonies, Currais Islands, PR, south side, 12 m, 19 July 2002.

DZUFPR - DID 157: 1 colony, Currais Islands, PR, north side, 8 m, 19 July 2002.

DZUFPR - DID 164: 3 colonies, Currais Islands, PR, south side, 9-12 m, 04 October 2002.

DZUFPR - DID 165: 1 colony, Currais Islands, PR, north side, 04 October 2002.

DZUFPR - DID 178: 1 colony, Currais Islands, PR, south side, 12 m, 31 January 2003.

DZUFPR - DID 179: 1 colony, Currais Islands, PR, north side, 8 m, 31 January 2003.

Figure 5. Didemnum sp. (A) Thorax; (B) abdomen. Scale bar: $200 \mu m$.

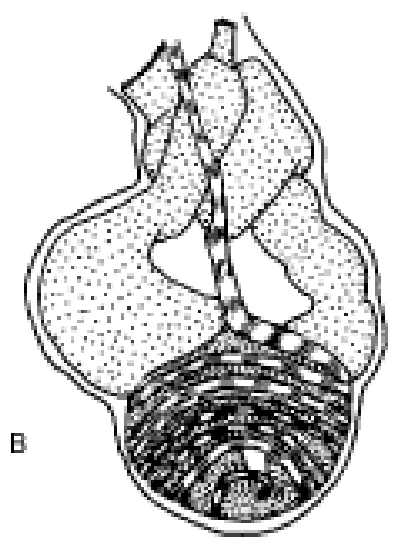

http://www.biotaneotropica.org.br 
The colony is encrusting and marbled due to the dark pigment (black or dark purple) on the cloacal channels and around the cloacae, contrasting with the beige color of the rest of the tunic. After fixation the colony becomes chocolate-brown and beige. The tunic is firm and brittle. Cloacae are conical with oval openings. Spicules are uniformly and densely distributed in the surface of the tunic, but in low density in the rest of the colony. Spicules are small (20-30 $\mu \mathrm{m})$, globular, with a small number of conical and short rays, sometimes with rounded tips. Zooids are $1.0 \mathrm{~mm}$ long, with the thorax and abdomen of equal length. The body wall is dark brown. The long, tubular, oral siphon has six triangular lobes and conspicuous circular musculature. The atrial opening is lateral and wide, without a dorsal languet. The muscular process is longer than the abdomen, arising from the esophageal-rectal peduncle. The thoracic organ is salient in shell form, but not observed in all individuals. The pharynx has four rows of stigmata. In one bud seven stigmata were found in one half of the anterior row while six stigmata were found in the others. The esophagus is short and the esophageal-rectal peduncle presents a very evident constriction. The stomach is round and smooth and the duodenum is as long as the stomach. The single testicle is surrounded by six or seven turns of the sperm duct, and located posterior in the intestinal loop. The ovary has two oocytes, anterior to the testis, and the sperm duct usually covers the larger oocyte. There were no larvae.

\section{Remarks}

The absence of larvae in the examined material hindered comparisons with other didemnid species, although the appearance of the colony is quite different from any species described from Brazil and the Atlantic. This suggests that the present material may represent a new species.

\section{Family DIDEMNIDAE Verrill, 1871}

Genus Trididemnum Della Valle, 1881

Trididemnum orbiculatum (Van Name, 1902)

(Figure 4F)

\section{Examined material}

DZUFPR - DID 160: 1 colony, Currais Islands, PR, north side, 8 m, 19 July 2002.

DZUFPR - DID 170: 1 colony, Currais Islands, PR, south side, 04 October 2002.

The colony is encrusting and transparent with black spots caused by the accumulation of pigment on the oral siphons of the zooids. The tunic is mucous, with low spicule density at the surface and absence of spicules in the base and medium layer. The muscular process is shorter than the abdomen, arising from the esophageal-rectal peduncle. The thoracic organ is round and salient, positioned between the en- dostyle and the border of the body wall. There are three rows of stigmata in the pharynx. The atrial siphon is tubular and horizontal. The testis has one follicle surrounded by 5-6 turns of the sperm duct and the ovary with two small oocytes. There were no larvae in the examined material.

\section{Remarks}

The genus Trididemnum in Brazil is represented by $T$. orbiculatum (T. thetidis and T. orbiculatum are synonymous) (Van Name 1945, Rodrigues \& Rocha 1993) and T. maragogi (Rocha, 2002). Recently T. solidum (Van Name, 1902) and Trididemnum sp. have been reported from the Brazilian coast (Lotufo 2002). The examined material was identified as $T$. orbiculatum mainly because of the shape, quantity and distribution of the spicules and the color of the colony. There were no larvae in the examined material.

Order PLEUROGONA Perrier, 1898

Suborder STOLIDOBRANCHIA Lahille, 1887

Family STYELIDAE Sluiter, 1895

Genus Botryllus Gaertner, 1774

Botryllus tuberatus Ritter \& Forsyth, 1917

Examined material

DZUFPR - DID 151: 1 small colony on Didemnum granulatum, Currais Islands, PR, south side, 12 m, 19 July 2002.

The colony is encrusting and $4 \mathrm{~mm}$ in diameter. The tunic is transparent, thin and delicate. Zooids are sac-like, $0.6 \mathrm{~mm}$. The tubular oral siphon has a smooth margin; the atrial opening is wide, with a long and pointed dorsal languet. The body wall is translucent and strongly pigmented brown, thus hiding the internal structures. The pharynx has four rows of stigmata.

\section{Remarks}

Several species of Botryllus have been reported in Brazil: B. giganteum Aron \& Sole-Cava, 1991, B. tabori Rodrigues, 1962 and B. tuberatus Ritter \& Forsyth, 1917 occur in the coast of the state of São Paulo (Rodrigues et al. 1998), B. planus (Van Name, 1902) and B. schlosseri (Pallas, 1766) occur on the tropical Brazilian coast (Lotufo 2002). Among them, only B. tuberatus has four rows of stigmata.

Family STYELIDAE Sluiter, 1895 Genus Polyandrocarpa Michaelsen, 1904 Polyandrocarpa anguinea (Sluiter, 1898)

Examined material

DZUFPR - STY 099: 1 colony, Currais Islands, PR, north side, 8-9 m, 31 January 2003. 
The colony is $5.5 \mathrm{~cm}$ long and $3 \mathrm{~cm}$ thick, comprising a compact mass of zooids, with siphons projecting from the colony surface. The tunic is firm and wrinkled with encrustations. Zooids are $1.5 \mathrm{~cm}$ long, yellowish with a very delicate body wall, usually tearing during removal from the tunic. Approximately 22 thin oral tentacles, of two sizes. The neural gland opening is " $C$ " shaped with the ends of the "C" curved inward. The pharynx comprises four folds on each side. The longitudinal vessels were arranged in the following manner in one example: right E 712716413511 2 DL $4144107128127 \mathrm{E}$ left. The abdomen is formed by a globular stomach, with 13 longitudinal folds, without a caecum. The intestinal loop contains no endocarp, and the anus is fringed by many lobes. The gonads are sac like, loosely connected to the body wall. In one example we counted 15 in the right side and 10 in the left side of the body; in another 15 in the right and two in the left.

\section{Remarks}

Only two species of Polyandrocarpa have been found in Brazil: Polyandrocarpa anguinea (Sluiter, 1898) and P. zorritensis (Van Name 1931). P. zorritensis has smaller zooids each in its tunic and attached to each other only by branching and root-like stolons. The colony may be covered by sand (Van Name 1945).

\section{Family STYELIDAE Sluiter, 1895}

Genus Symplegma Herdman, 1886

Symplegma brakenhielmi (Michaelsen, 1904)

\section{Examined material}

DZUFPR - STY 096: 1 colony, Currais Islands, PR, south side, 04 October 2002.

The colony has a very thin tunic and protuberant zooids. In formalin, the colony is uniformly brown and the tunic is transparent and delicate. The color comes from the zooids. The body is flattened dorso-ventrally, measuring up to $4 \mathrm{~mm}$ in length. There are six long, and a variable number of smaller, oral tentacles, all of which have a large base and pointed tip. The dorsal tubercle forms a swollen region around the small circular aperture. The pharynx has ten rows of stigmata. The first two longitudinal vessels of the left side are not parallel with the others, turning towards, and contacting the dorsal lamina at the fourth and sixth rows of stigmata. The caecum of the stomach has two connections with the intestinal loop, the first arising from the base of the caecum and the second, from the curve of the caecum. The testis has one or two anterior lobes and two or three posterior lobes, and the ovary has up to eight oocytes in each side. No larvae were found.

\section{Remarks}

In addition to $S$. brakenhielmi, the species reported from Brazil are S. rubra Monniot, 1972 and S. viride Herdman,
1886. However, in a recent revision of specimens from the state of São Paulo, no S. viride were found (Couto 2003). Symplegma brakenhielmi was diagnosed by the color of the body wall, a discontinuous prepharyngeal groove with a swollen region around the dorsal tubercle, weakly lobed testicular follicles and the presence of two tissue connections between the caecum and the intestine. Symplegma rubra, on the other hand, has a continuous prepharyngeal groove that usually covers the small opening of the dorsal tubercle, has very lobed testicular follicles and three tissue connections between the caecum and the intestine.

\section{Family PYURIDAE Hartmeyer, 1908 \\ Genus Microcosmus Heller, 1878 \\ Microcosmus exasperatus Heller, 1878}

(Figure 6)

\section{Examined material}

DZUFPR - PYU 042: 2 individuals, Currais Islands, PR, 31 January 2003.

DZUFPR - PYU 043: 1 individual, Currais Islands, PR, 31 January 2003.

The globular body is enclosed within a leathery and wrinkled tunic. The animals were about $2.5 \mathrm{~cm}$ in height and $3 \mathrm{~cm}$ in width (other animals more or less the same size). The tunic is orange or purple, maintaining color in formalin, and contains some sand and encrusting organisms on the surface. Both siphons are lobed with four triangular lobes. There are 12 large and 18 smaller branched oral tentacles arranged on a muscular ring. The prepharyngeal groove is double, the neural gland opening U-shaped with very inrolled horns. The pharynx has 8 folds on each side, but the ventral fold on the right side is incomplete. The longitudinal vessels were disposed in the following manner in one exemplar: right E $2124173184205175204155183 \mathrm{DL}$ 421414418616717516513382 E left. One gonad on each side of the body is formed by 3 - -5 masses of testis follicles surrounding a tubular ovary.

\section{Remarks}

Two species of the genus Microcosmus have been reported from the Brazilian coast: Microcosmus exasperatus Heller, 1878 and Microcosmus helleri Herdman, 1881. Microcosmus helleri differs from $M$. exasperatus by the smaller number of branchial folds, the gut loop is less bent upwards at the anterior end and there is a more compacted gonad, not divided into segments (Van Name 1945). Microcosmus squamiger has the gonads also divided into three lobes and has been confused with $M$. exasperatus, but the siphonal spines are very different, with roof-tile 

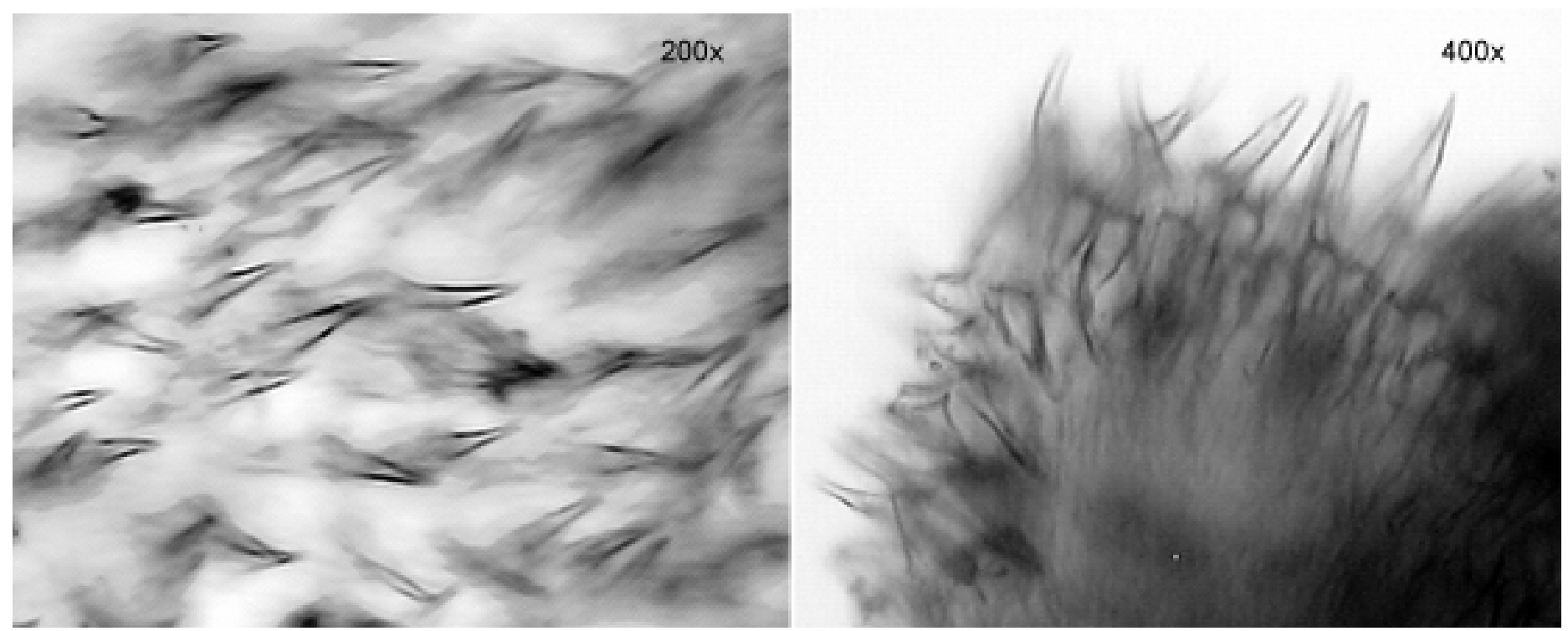

Figure 6. Microcosmus exasperatus Heller, 1878. Siphonal spines.

shape and spiny rims (Monniot et al. 2001). Microcosmus exasperatus is widely distributed in all oceans and, in the western Atlantic Ocean, its southern distributional limit is Santa Catarina (Van Name 1945).

\section{Family MOLGULIDAE Lacaze-Duthiers, 1877 \\ Genus Molgula Forbes, 1848 \\ Molgula phytophila Monniot, 1969-70}

\section{Examined material}

DZUFPR - MOL 014: 2 individuals, Currais Islands, north side, 8-9 m, 31 January 2003.

Individuals are small, approximately $5 \mathrm{~mm}$ in length. The tunic is thin, delicate and encrusted with sand. The body is $3 \mathrm{~mm}$ long without the tunic, slightly flattened dorsal-ventrally. The body wall is also transparent and delicate. Both siphons have 12 pointed or triangular lobes and conspicuous musculature, both circular and longitudinal. The longitudinal muscles form wide bands that extend obliquely up to $1 / 3$ of the body. There are 10 long, branched oral tentacles. The prepharyngeal groove is double-walled. The dorsal lamina has a smooth margin. The pharynx has seven folds on each side, and each fold has two longitudinal vessels. The stigmata are spiral-shaped, but infundibula were not visible in the examined material. The abdomen includes a short esophagus, a tubular stomach overlaid by the lamellar digestive gland. The gonads are elongate and compact, the right one accompanies the renal sac dorsally, and the left lies inside the secondary intestinal loop. Several embryos were in the atrial cavity.

\section{Remarks}

Molgula phytophila has already been found on the coast of Santa Catarina, to the south of the Currais Islands (Rocha \& Moreno 2000). All the diagnostic characters (Monniot 1969-70) were found in these specimens: seven folds on each side of the pharynx, presence of two longitudinal vessels in each fold, the form and disposition of the gonads, and the presence of brooded embryos.

\section{Ecological Section}

The genus Didemnum (species $D$. rodriguesi, $D$. granulatum and D. speciosum) was the most common. Didemnum granulatum and $D$. speciosum, because they were difficult to distinguish in the field, were treated as one species (white didemnids) in the first field sample period (winter, Table 1). During subsequent samplings, both $D$. granulatum and D. speciosum were identified in the field and showed contrasting vertical patterns in the summer: $D$. granulatum was increasingly common from deep to shallow water $(G=20.18 ; P<0.05)$ while $D$. speciosum showed the reverse trend $(G=13.1 ; P<0.05$; Table 1$)$. Both species were very uncommon in winter (Table 2 ). Didemnum rodriguesi showed no difference in abundance between seasons (Table 2 ), but in the summer, when three depths were sampled, it was more abundant in shallow water $(G=8.64$; $\mathrm{P}<0.05)$. In the other seasons considered together, it was more abundant in the medium depth $(\mathrm{G}=22.8$; $\mathrm{P}<0.05)$ (Table 1). Pooling data across seasons, this species was more abundant on the north than on the south $(\mathrm{G}=9.81$; $\mathrm{P}<0.05)$ (Table 1). It was not found in the spring in shallow transects nor in summer in deep transects. 
Table 1. Comparison of occurrence frequencies for selected ascidian species between north and south sides, and at three depths, at Currais Islands.

\begin{tabular}{|c|c|c|c|c|c|c|c|}
\hline \multirow[b]{2}{*}{ WINTER (July, N=81) } & \multicolumn{2}{|c|}{ Orientation } & \multicolumn{4}{|c|}{ Depth (m) } & \multirow{2}{*}{$\mathrm{G}^{\mathrm{a}}$} \\
\hline & $\mathrm{N}$ & $\mathrm{S}$ & & $<10$ & 1012 & $>12$ & \\
\hline White didemnids & 18 & 16 & 0.29 & 20 & 14 & - & 1.6 \\
\hline Diplosoma spp. & 3 & 1 & 1.15 & 3 & 1 & - & 1.05 \\
\hline \multicolumn{8}{|c|}{ SPRING (October, N=137) } \\
\hline D. granulatum & 5 & 6 & 0.02 & 5 & 6 & - & 1.01 \\
\hline D. speciosum & 28 & 17 & $5.90^{\star}$ & 22 & 23 & - & 3.32 \\
\hline Diplosoma spp. & 3 & 13 & $6.45^{\star}$ & 16 & 0 & - & $17.83^{\star}$ \\
\hline \multicolumn{8}{|c|}{ SUMMER (January, N=160) } \\
\hline D. granulatum & 12 & 18 & 1.49 & 17 & 13 & 0 & $20.18^{\star}$ \\
\hline D. speciosum & 19 & 26 & 1.52 & 10 & 15 & 20 & $13.1^{*}$ \\
\hline \multicolumn{8}{|c|}{ NON-SEASONAL SPECIES } \\
\hline D. rodriguesi & 30 & 12 & $9.81^{*}$ & $4 / 8^{b}$ & $29 / 5$ & -10 & $22.82^{\star} / 8.64^{\star}$ \\
\hline Didemnum sp. & 6 & 6 & 0.01 & $4 / 3$ & $4 / 1$ & -10 & $0.14 / 2.8$ \\
\hline C. oblonga & 15 & 2 & $12.3^{\star}$ & $9 / 3$ & $3 / 1$ & $-/ 1$ & $1.89 / 3.6$ \\
\hline
\end{tabular}

${ }^{\mathrm{a}} \mathrm{G}$, Log-likelihood ratio test. ${ }^{*}, \mathrm{P}<0.05$.

${ }^{\mathrm{b}}$ In Summer three depths were sampled. The numerator therefore is a comparison between Winter and Spring (two depths) while the denominator is a comparison among all three seasons (three depths).

Table 2. Seasonal occurrence of ascidian species, at Currais Islands.

\begin{tabular}{|c|c|c|c|c|}
\hline & \multicolumn{3}{|c|}{ Season } & \multirow{2}{*}{ G } \\
\hline & $\begin{array}{c}\text { WINTER } \\
\text { (July, N=81) }\end{array}$ & $\begin{array}{c}\text { SPRING } \\
\text { (October, } \mathrm{N}=137 \text { ) }\end{array}$ & $\begin{array}{c}\text { SUMMER } \\
\text { (January, N=160) }\end{array}$ & \\
\hline Didemnum speciosum & 5 & 45 & 45 & $25.1 *$ \\
\hline Didemnum granulatum & 4 & 11 & 30 & $13.1^{*}$ \\
\hline Didemnum rodriguesi & 10 & 19 & 13 & 2.68 \\
\hline Didemnum sp. & 2 & 6 & 4 & 0.98 \\
\hline Diplosoma spp. & 4 & 16 & 0 & $25.85 *$ \\
\hline Clavelina oblonga & 6 & 6 & 5 & 2.13 \\
\hline
\end{tabular}


Table 3. Percentage of $25 \mathrm{~cm}^{2}$ quadrats with rare ascidian species at Currais Islands.

\begin{tabular}{|c|c|c|c|c|c|}
\hline & \multicolumn{3}{|c|}{ Season } & \multicolumn{2}{|c|}{ Orientation } \\
\hline & $\begin{array}{c}\text { Winter (July) } \\
\mathrm{N}=81\end{array}$ & $\begin{array}{c}\text { Spring (October) } \\
\mathrm{N}=137\end{array}$ & $\begin{array}{c}\text { Summer (January) } \\
\mathrm{N}=160\end{array}$ & $\begin{array}{c}\text { North } \\
(\mathrm{N}=185)\end{array}$ & $\begin{array}{c}\text { South } \\
(\mathrm{N}=193)\end{array}$ \\
\hline Trididemnum orbiculatum & 1.3 & 0.7 & 0.0 & 1.1 & 0.0 \\
\hline Distaplia bermudensis & 0.0 & 0.0 & 0.6 & 0.5 & 0.0 \\
\hline Eudistoma carolinense & 0.0 & 2.9 & 1.2 & 2.2 & 1.0 \\
\hline Eudistoma sp. & 0.0 & 0.7 & 0.0 & 0.5 & 0.0 \\
\hline Aplidium pentatrema & 0.0 & 0.7 & 0.0 & 0.5 & 0.0 \\
\hline Molgula phytophila & 0.0 & 0.0 & 0.6 & 0.5 & 0.0 \\
\hline Botryllus tuberatus & 1.3 & 0.0 & 0.0 & 0.0 & 0.5 \\
\hline Polyandrocarpa anguinea & 0.0 & 0.0 & 0.6 & 0.5 & 0.0 \\
\hline
\end{tabular}

Diplosoma spp. includes both $D$. listerianum and $D$. sp., which could not be separated in the field. Uncommon in winter and absent in summer (Table 2), Diplosoma was more often encountered in shallow transects $(\mathrm{G}=17.83$; $\mathrm{P}<$ 0.05 ) and on the south side of the island $(\mathrm{G}=6.45 ; \mathrm{P}<0.05)$ in spring (Table 1). Didemnum sp. occurred in all samples with low frequency (Table 2) and without differences between location and depths (Table 1).

Clavelina oblonga occurred in all seasons (Table 2), more commonly on the north side of the island ( $\mathrm{G}=12.3$; $\mathrm{P}<0.05$ ) (Table 1). Additionally, Trididemnum orbiculatum, Distaplia bermudensis, Eudistoma carolinense, Eudistoma sp., Aplidium pentatrema, Molgula phytophila, Botryllus tuberatus and Polyandrocarpa anguinea were rare with only one or two occurrences (Table 3).

At this island, ascidians in general showed no vertical distribution patterns, perhaps due to the great seasonal variation in species abundance. Four species did show variation in occurrence by depth: $D$. rodriguesi was more frequent in medium depth in spring and in shallow water in summer, Diplosoma spp. was more frequent in shallow water in spring, $D$. granulatum was more frequent in shallow water in summer, while $D$. speciosum was more frequent in deep water in summer (Table 1).

Some species also showed geographical tendencies related to the side of the island. Didemnum rodriguesi and Clavelina oblonga were most frequent on the north side of the island, Didemnum speciosum was also most frequent on the north side in spring, and Diplosoma spp. were most frequent in the south in spring (Table 1). Also, Trididemnum orbiculatum, Distaplia bermudensis, Eudistoma sp., Aplidium pentatrema, Molgula phytophila and Polyandrocarpa anguinea occurred exclusively on the north side of the island and Botryllus tuberatus on the south side (Table 3), but were uncommon. Further studies will be required to determine whether these species indeed have geographical tendencies or whether this restricted distribution was due to sampling methods.

\section{Discussion}

Fifteen ascidian species were recorded in the transects with an additional five species encountered in the area while gathering the data. One of these is a new species for the Currais Islands: Eudistoma sp. (being described elsewhere). An additional two species may also be new, pending further study: Didemnum sp. and Lissoclinum sp., (see taxonomic session). Aplidium pentatrema is a new record for Brazil, and another nine species were found for the first time in the state of Paraná: Perophora regina, Didemnum speciosum, Diplosoma sp., Trididemnum orbiculatum, Eudistoma carolinense, Botryllus tuberatus, Symplegma brakenhielmi, Polyandrocarpa anguinea and Molgula phytophila. 
The presence of Aplidium pentatrema in the Currais Islands could be explained by the existence of a major port receiving approximately 1,500 large ships each year, thus potentially being a source of introduction of this normally warm-water species. Aplidium pentatrema, described by Monniot (1972) from the Bermudas, until now was only known from the type locality and Guadalupe (Monniot 1983), so it is surprising to find it here in colder subtropical waters. However, our knowledge of Brazilian ascidians is still very incomplete. Eudistoma carolinense has also a very intriguing distribution: Florida (Van Name 1945), northern Brazil (Millar 1977) and southern Brazil (Rocha \& Moreno 2000, and in the present study). It has not been reported in the intervening states within Brazil (Lotufo 2002, Rodrigues et al. 1998). This distributional gap does not simply reflect the lack of sampling effort because this species occurs in intertidal zones and is easy to collect. The species was first collected in the south in 1994 but no ascidians were collected here prior to this date. Many species of ascidians have been recently reported as invasive, and currently have wide geographical distributions due to dispersal by ships (Lambert 2001).

For Symplegma brakenhielmi and Microcosmus exasperatus, the coast of the state of Paraná seems to be their southern distributional limit in the West Atlantic. The other species have already been recorded further south in Brazil: Didemnum rodriguesi, D. granulatum, D. speciosum, Diplosoma listerianum, Clavelina oblonga, Distaplia bermudensis, Botryllus tuberatus, Polyandrocarpa anguinea and Molgula phytophila (Rocha et al. 1999, Rocha \& Moreno 2000).

A vertical pattern of distribution was not generally observed. However, Didemnum rodriguesi, D. granulatum, and Diplosoma spp. were more frequent in shallow water, while $D$. speciosum was more frequent in deep water, but none of these species showed the same pattern in all seasons. The range in depths in this study was narrow because the maximum depth around the island is $18 \mathrm{~m}$, and most of the species were equally distributed between 6 and $15 \mathrm{~m}$. However, abundance and diversity were much reduced at $15 \mathrm{~m}$, and this could possibly indicate an important shift in habitat conditions for these animals. Even in this shallow region, a marked thermocline forms during the summer when the Central South Atlantic waters penetrate beneath the warmer surface waters (Brandini 1990 in Silva 2001). Temperatures near the bottom may reach $13^{\circ} \mathrm{C}$ (personal observation), and low temperature can retard growth or kill ascidians (Grosholz 2001). Another possible explanation for low ascidian abundance at $18 \mathrm{~m}$ is the proximity to the bottom, and its associated sand, continually re-suspended by water currents. A population of Ascidia sp. was destroyed after a disturbance of the sea-bed and the resulting increased turbidity (Monniot 1965). Thus, further studies, perhaps experimental, will be required to test which factors influence the abundance of ascidians in deeper waters.
Other studies have analyzed vertical distribution patterns for ascidians within the same depths as this study. Microcosmus sabatieri, for instance, has different depth distributions depending on the amount of illumination received and this varies with the inclination of the substrate (the upper limit of $M$. sabatieri is $15 \mathrm{~m}$ on horizontal surfaces and $0.5 \mathrm{~m}$ on under surfaces) and its orientation (the upper limit is 7-8 $\mathrm{m}$ on substrates facing south and 3-4 $\mathrm{m}$ on substrates facing north) (Monniot 1965). Light intensity seems to be the most important factor limiting spatial distribution of Didemnum granulatum at Eilat, Red Sea. Oren \& Benayahu 1998 reported that this species recruited faster and more intensively on experimental plates at $31 \mathrm{~m}$ than on shallower plates, but where the maximum depth was $17 \mathrm{~m}$ it also recruited more intensively on the deepest $17 \mathrm{~m}$ plates. Transplanted cuttings to shallower vertical and the top of horizontal plates resulted in complete mortality. Didemnum granulatum at the Currais Islands showed a different pattern, being more abundant above $12 \mathrm{~m}$. Future studies may determine whether this is a consequence of very poor water transparency in Currais Islands or the result of interspecific interactions after recruitment.

Depth zonation of ascidians was also observed on Deer Island of the Bay of Fundy, Canada, where phototransects up to $140 \mathrm{~m}$ depth showed that some species occurred only at $<20 \mathrm{~m}$ and others reached peak densities between 60 and $90 \mathrm{~m}$ (Hatfield et al. 1992). Since maximum light penetration is only $14 \mathrm{~m}$ in that region, light is probably not the factor limiting ascidian distribution. Strong tidal currents may be the most important environmental limitation in that study.

The south side of Currais Islands is more exposed to waves and currents, while the northern face is more protected. Since intense hydrodynamics can limit the occurrence of more sensitive ascidian species because of turbulence (Monniot 1965, Hatfield et al. 1992), we anticipated differences in species composition or abundance between the two sides of the island. Indeed, Didemnum rodriguesi, Clavelina oblonga and Didemnum speciosum were either more common on the north side of the island, or equally common on both sides, depending upon the season. Trididemnum orbiculatum, Distaplia bermudensis, Eudistoma sp., Aplidium pentatrema, Molgula phytophila and Polyandrocarpa anguinea occurred exclusively on the northern face, but because of their uncommonness, this pattern may be spurious. Botryllus tuberatus was found only on the south and may prefer an exposed substrate; Van Name (1945) lists its California distribution occuring on kelp fronds and rocks in exposed areas. These considerations suggest that the north side of the island (more protected) could be richer in ascidians.

While spatial distribution patterns were subtle or absent, temporal distribution showed more obvious patterns within the year studied. In spring, both the number 
and abundance of species were greater than in other seasons. In summer, only D. speciosoum and D. granulatum had an abundance peak, and Diplosoma spp., which was very common in the spring, was absent. Colony growth and reproduction peaked in spring in four of five species studied in the Mediterranean, and summer was the period of colony regression for many which was attributed to excessive heat (Turon \& Becerro 1992). A slightly different situation has been observed in Phallusia nigra Savigny, 1816 at São Sebastião, $400 \mathrm{~km}$ to the north of Currais Islands: the peak of abundance occurred in the fall (recruitment) and the peak of growth in spring and summer (Rocha et al. 1999).

In conclusion, an abundant and species-rich colonial ascidian community is present at the Currais Islands, with Didemnum rodriguesi, D. speciosum and D. granulatum being the most abundant. Twenty species were recorded, of which one (and possibly another two) are new species. Ascidians are distributed between 6 and $15 \mathrm{~m}$, with no striking patterns of vertical distribution. There are some suggestions that the north side of the island may be richer in ascidians than the south side, but future work will be required to test that hypothesis. A clear temporal variation in abundance was observed, with the greatest abundance of species and individuals in the spring, but we do not know if this pattern in repeatable between years.

\section{Acknowlwdgements}

We would like to thank the ECOPLAN Institute that generously provided us with the transport and diving logistics during field trips, Dr James Roper for statistical advice and revision of the English text, Carlos W. Hackradt, Rafael Metri and Igor S. de Oliveira for assistance in field work, and CNPq for a research grant to RMR. This paper is the contribution 1424 of Departamento de Zoologia, Universidade Federal do Paraná.

\section{References}

COUTO, A.C.F. 2003. Estudo taxonômico das ascídias do gênero Symplegma (Tunicata, Ascidiacea, Styelidae) encontradas no canal de São Sebastião, SP. Dissertação, Universidade de São Paulo, São Paulo, Brazil.

GOODBODY, I. \& COLE, L. 1987. A new species of Perophora (Ascidiacea) from the Western Atlantic, including observations on muscle action in related species. Bull. Mar. Sci. 40:246--254.

GOODBODY, I. 1994. The tropical Western Atlantic Perophoridae (Ascidiacea): I. The genus Perophora. Bull. Mar. Sci. 55:176--192.

GROSHOLZ, E. 2001. Small spatial-scale differentiation among populations of an introduced colonial invertebrate. Oecologia 129:58--64.
HATFIELD, C., LOGAN, A. \& THOMAS, M.L.H. 1992. Ascidian depth zonation on sublittoral hard substrates off Deer Island, New Brunswick, Canada. Estuar. Coast. Shelf Sci. 34:197--202.

HERDMAN, W.A. 1886. Report on the Tunicata collected during the years 1873-1876. Part 2, Ascidiae compositae Zool. Chall. Exp. 14:1-425.

HURLBUT, C.J. 1991. The effects of larval abundance, settlement and juvenile mortality on the depth distribution of a colonial ascidian. J. Exp. Mar. Biol. Ecol. 150:183--202.

HURLBUT, C.J. 1993. The adaptive value of larval behavior of a colonial ascidian. Marine Biology 115:253--262.

KOTT, P. 1992. The Australian Ascidiacea part 3, Aplousobranchia (2). Mem. Queensl. Mus. 32:375--620.

KOTT, P. 2001. The Australian Ascidiacea Part 4, Aplousobranchia (3), Didemnidae. Mem. Queensl. Mus. 47:1--410.

LAFARGUE, F. 1968. Les peuplements sessiles de l'Archipel de Glénan. II. Les Didemnidae-Systématique-Écologie. Vie Milieu 19:353--446.

LAFARGUE, F. \& WAHL, M. 1987. The didemnid ascidian fauna of France. Ann. Inst. Oceanogr. Paris, 63:1--32.

LAMBERT, G. 2001. A global overview of ascidian introductions and their possible impact on the endemic fauna. In The Biology of Ascidians (H. Sawada, H. Yokosawa and C.C. Lambert, eds.). Springer Verlag, Tokyo, p.249-257.

LOTUFO, T.M.C. 2002. Ascidiacea (Chordata: Tunicata) do litoral tropical brasileiro. PhD thesis. Instituto de Biociências da Universidade de São Paulo, São Paulo, Brazil.

MILLAR, R.H. 1971. The biology of ascidians. Adv. Mar. Biol.9:1--100.

MILLAR, R.H., 1977. Ascidians (Tunicata: Ascidiacea) from the northern and north-eastern Brazilian shelf. J. Nat. Hist. 11:169--223.

MONNIOT, C. 1965. Étude systématique et évolutive de la Famille des Pyuridae (Ascidiacea). Mem. Mus. natl Hist. Nat., Paris, sér. A, 36:1--203.

MONNIOT, C. 1969-70. Campagne de la Calypso au large des cotes Atlantiques de l’Amérique du Sud (1961-1962). Première partie (suite). 17 Ascidies Phlébobranches et Stolidobranches. Ann. Inst. Oceanogr. Paris, 36:33--59.

MONNIOT, C. \& MONNIOT, F. 1987. Les ascidies de Polynésie française. Mem. Mus. natl Hist. Nat., Paris, sér.A, Zoologie, 136:1--155.

MONNIOT, C., MONNIOT, F. \& LABOUTE, P. 1991. Coral Reef Ascidians of New Caledonia. Orstom Editions, Paris.

MONNIOT, C., MONNIOT, F., GRIFFITHS, C.L. \& SCHLEYER, M. 2001. South African ascidians. Ann. S. Afr. Mus. 108: 1-141. 
MONNIOT, F. 1972. Ascidies aplousobranches des Bermudes. Polyclinidae et Polycitoridae. Bull. Mus. Hist. Nat., Paris, 3e sér. (82), Zoologie, 61: 949--962.

MONNIOT, F. 1974. Ascidies littorales et bathyales recoltées au cours de la campagne Biacores: Aplousobranches. Bull. Mus. Hist. Nat., Paris, 3e sér. (251), Zoologie, 173: 1287-1325.

MONNIOT, F. 1983. Ascidies littorales de Guadeloupe. I. Didemnidae. Bull. Mus. Hist. Nat., Paris, 4e sér., section A, 5: 5--49.

MONNIOT, F. 1983. Ascidies littorales de Guadeloupe. III. Polyclinidae. Bull. Mus. Hist. Nat., Paris, 4e sér., section A, 5: 413--422.

MONNIOT, F. 1994. Ascidies de Nouvelle-Calédonie. XIV. Le genre Diplosoma (Didemnidae). Bull. Mus. Hist. Nat., Paris, 4e sér., section A, 16: 3--11.

MOURE, J.S., BJORNBERG T.K.S. \& LOUREIRO, T.ST. 1954. Protochordata ocorrentes na entrada da Baía de Paranaguá. Dusenia 5: 233--242.

NISHIKAWA, T. 1990. The ascidians of the Japan Sea. I. Publ. Seto Mar. Biol. Lab. 34: 73--148.

OLSON, R.R. 1983. Ascidian-Prochloron symbiosis: The role of larval photo-adaptations in midday larval release and settlement. Biol. Bull. 165: 221--240.

OMURO, J.Y. \& ROCHA, R.M. 2000. Distribuição e abundância de ascídias na Reserva Biológica Marinha do Arvoredo, Santa Catarina, Brasil. In Anais da XIII Semana Nacional de Oceanografia, Universidade do Vale do Itajaí, Santa Catarina, Brasil, p. 706--708.

OREN, U. \& BENAYAHU, Y. 1998. Didemnid ascidians: rapid colonizers of artificial reefs in Eilat (Red Sea). Bull. Mar. Sci. 63: 199--206.

ROCHA, R. M. 2002. Trididemnum maragogi sp. nov. (Ascidiacea, Didemnidae) from Alagoas, Northeastern Brazil. Revta Bras. Zool. 19: 1105-1110.

Rocha, R. M. \& Monniot, F. 1993. Didemnum rodriguesi sp. nov. - a new didemnid ascidian common to southeastern Brazil and New Caledonia Ann. Inst. Oceanogr., Paris, 69: 261-265.

ROCHA, R.M. \& MONNIOT, F. 1995. Taxonomic and ecological notes on some Didemnum species (Ascidiacea, Didemnidae) from São Sebastião Channel, South - Eastern Brazil. Revta Bras. Biol. 55: 639--649.

ROCHA, R.M. \& MORENO, T.R. 2000. Ascidians associated with Eudistoma carolinense Van Name, 1945. With description of a new species of Polycarpa. Ophelia 52: 9--16.

ROCHA, R.M. \& NASSER, C.M. 1998. Some ascidians (Tunicata, Ascidiacea) from Paraná State, Southern Brazil. Revta Bras. Zool. 15: 633--642.

ROCHA, R.M., LOTUFO, T.M.C. \& RODRIGUES, S.A. 1999. The biology of Phallusia nigra Savigny, 1816 (Tunicata, Ascidiacea) in southern Brazil: spatial distribution and reproductive cycle. Bull. Mar. Sci. 64: 77--87.
ROCHA, R.M., MORENO, T.R. \& METRI, R. 1999. Ascídias da Reserva Biológica Marinha do Arvoredo, Santa Catarina, Brasil. In Livro de Resumenes Ampliados del VIII Congresso Latinoamericano sobre Ciencias del Mar(A.E.T. Aguilar \& Z.G.C. Malpica, eds.), Trujillo, Peru, p. 432--433.

RODRIGUES, S.A. \& ROCHA, R.M. 1993. Littoral compound ascidians (Tunicata) from São Sebastião, Estado de São Paulo, Brazil. Proc. Biol. Soc. Wash. 106: 728--739.

RODRIGUES, S.A., ROCHA, R.M. \& LOTUFO, T.M.C. 1998. Guia Ilustrado para Identificação das Ascídias do Estado de São Paulo. FAPESP, Editora Parma Ltda, São Paulo.

ROWE, F.W.E. 1966. A review of the genus Diplosoma Macdonald, 1859 with a description of the proposed new type Diplosoma listerianum. Ann. Mag. Nat. Hist. 13: 457--467.

SILVA, A.S. 2001. Estrutura e dinâmica de comunidades epilíticas de habitats artificiais e suas relações com os fatores ambientais na plataforma rasa do estado do Paraná. Tese de doutorado, Universidade Federal do Paraná, Paraná, Brasil.

TOKIOKA, T. 1954. Invertebrate fauna of the intertidal zone of the Tokara Island. Publ. Seto Mar. Biol. Lab. 3: 239--264.

TURON, X. 1990. Distribution and abundance of ascidians from a locality on the Northeast Coast of Spain. Mar. Ecol. 11: 291--308.

TURON, X. \& BECERRO, M.A. 1992. Growth and survival of several ascidian species from the northwestern Mediterranean. Mar. Ecol. Prog. Ser. 82: 235--247.

VAN NAME, W. G. 1945. The North and South American ascidians. Bull. Am. Mus. Nat. Hist. 84: 1--476.

YOUNG, C.M \& CHIA, F.S. 1984. Microhabitat-associated variability in survival and growth of subtidal solitary ascidians during the first 21 days after settlement. Mar. Biol. 8: 61--68.

Title: Ascidians at Currais Islands, Paraná, Brazil: Taxonomy and Distribution

Authors: Rosana Moreira da Rocha \& Suzana Barros de Faria

Biota Neotropica, Vol. 5 ( number 2): 2005

http://www.biotaneotropica.org.br/v5n2/pt/ abstract?article+BN03105022005

Date Received: 09/03/2004 - Revised: 09/26/2005

Accepted: 10/10/2005

ISSN 1676-0611 